DOI: $10.17516 / 1997-1370-0749$

УДК $342.72 / .73$

\title{
Problems of Realization of the Rights of Russian Men to Reproductive Health
}

\author{
Galina N. Komkovaa, Rima A. Torosyana and Alla V. Basova ${ }^{\text {b* }}$ \\ ${ }^{a}$ Saratov State University \\ named after N.G. Chernyshevsky \\ Saratov, Russian Federation \\ ${ }^{b}$ Saratov State Medical University \\ named after V.I. Razumovsky \\ Saratov, Russian Federation
}

Received 15.03.2020, received in revised form 19.04.2021, accepted 30.04.2021

\begin{abstract}
The article presents an analysis of modern scientific literature and Russian legislation on legal regulation and the implementation of the right of men in Russia to protection of the reproductive health and specialized medical care. There were identified problems of the organization of andrological medical care for the male population in the Russian health care system, which affect the indicators of the incidence and life expectancy of men. It is proposed to improve Russian legislation regarding the training of andrologists and the organization of andrological medical care for the male population.
\end{abstract}

Keywords: right to health, reproductive rights, reproductive technologies, andrology, male infertility.

Research area: law.

Citation: Komkova, G.N., Torosyan, R.A., Basova, A.V. (2021). Problems of realization of the rights of Russian men to reproductive health. J. Sib. Fed. Univ. Humanit. Soc. Sci., 14(5), 662-668. DOI: $10.17516 / 1997-1370-0749$.

(C) Siberian Federal University. All rights reserved

* Corresponding author E-mail address: komkova_galina@mail.ru,rima_t@mail.ru, allsar@rambler.ru ORCID: 0000-0002-2572-2443 (Komkova); 0000-0001-8870-7809 (Torosyan); 0000-0001-9155-5957 (Basova) 


\title{
Проблемы реализации прав российских мужчин на репродуктивное здоровье
}

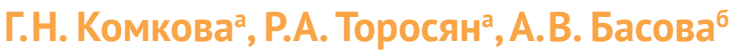 \\ ${ }^{a}$ Саратовский государственный университет \\ имени Н.Г Чернышевского \\ Российская Федерачия, Саратов \\ ${ }^{6}$ Саратовский государственный медицинский университет \\ имени В. И. Разумовского \\ Российская Федерачия, Саратов
}

\begin{abstract}
Аннотация. В представленной статье проведен анализ современной научной литературы и российского законодательства по вопросам правового регулирования и реализации права на охрану репродуктивного здоровья мужчин в России, оказания им специализированной медицинской помощи.

Выявлены проблемы организации оказания андрологической медицинской помощи мужскому населению в российской системе здравоохранения, что отражается на показателях их заболеваемости и продолжительности жизни мужчин.

Предлагается усовершенствовать российское законодательство в вопросах подготовки врачей-андрологов и организации оказания андрологической медицинской помощи мужскому населению.
\end{abstract}

Ключевые слова: право на здоровье, репродуктивные права, репродуктивные технологии, андрология, мужское бесплодие.

Научная специальность: 12.00.02 - конституционное право, муниципальное право, конституционный судебный процесс.

\section{Introduction}

According to Art. 40 of the Constitution of the Russian Federation, everyone has the right to protection of health and medical care. Article 2 of the Federal Law "On the Basics of Protecting the Health of Citizens in the Russian Federation" under health means the state of physiological, psychological, social well-being of a person, the absence of diseases, as well as disorders of body functions. However, unfortunately, recently there has been an increase in the general and special morbidity of the inhabitants of Russia. This can be attributed to the reproductive health of both men and women, which entails a deterioration in the demographic situation in the country. One of the reasons is the increase in the number of infertile married couples, now their number ranges from 8 to $21 \%$ in all couples of childbearing age, while in most cases infertility in these families is caused by a violation of the reproductive function of one of the spouses (Korobkov, 2016), which indicates the problems of ensuring reproductive health of the population. Despite the fact that the state takes certain measures to protect public health, the overall incidence rate among the male population remains quite high (Apolikhin, Moskaleva, Komarova, 2019). Against the background of high mortality among males of working age, the number of men with diseases of the reproductive system is also growing. Today, $78 \%$ of the total number of urological patients are boys and young men (Rybalchenko, 2015).

\section{Conceptological Framework}

A trend toward deterioration in male health indicators is noted by Professor A.A. Churakov indicating that in $20 \%$ of cases there is an idiopathic form of infertility in which it is not pos- 
sible to establish the exact cause of male infertility, which complicates the treatment process (Korobkov, 2016). Demographic indicators in the country are largely determined by a marked decrease in fertility in men of childbearing age (Korobkov, Vechkanova, 2016). The result is an increase in the proportion of the male factor in the structure of the causes of infertility up to $50 \%$ (Geneticheskie prichiny besplodiia (muzhskogo i zhenskogo)).

\section{Methodology}

Based on the presented indicators, it should be noted that the problem of ensuring male health in Russia is especially relevant at the present time.

Russian legislation does not fully ensure the implementation of the constitutional principle of equal rights and opportunities for men and women, if it concerns the quality of specialized medical care for men on a par with women. In our country, there are very few medical centers for the study of the reproductive system of men. There is a lack of some types of specialized medical care for men who have diseases of the genitourinary system, and there are no state programs for the protection of male reproductive health, which indicates the presence of gender discrimination of men in the provision of medical services.

This is evidenced by the fact that almost every medical institution has a department of women's consultation. A gynecologist is a doctor whose activities are aimed at treatment, diagnosis, prevention, and ensuring female reproductive health. However, it is quite difficult to find a specialist whose activities would be aimed at treating and ensuring male reproductive health (andrologist) (Torosyan, 2017).

\section{Discussion}

Despite the relevance and importance of the andrologist to ensure men's health, there is still no clear definition of the professional standard of the andrologists and their functions. Currently, there is a procedure for providing medical care in the profile of "pediatric urology-andrology" (Order of the Ministry of Health of Russia, 2012), however, there is no corresponding procedure for providing medi- cal care for adults in the profile of "andrology", while there is such a procedure for the profile of urology (Order of the Ministry of Health of Russia, 2012), gynecology (Order of the Ministry of Health of Russia, 2012) and many other areas of medicine.

The lack of an appropriate procedure for providing medical care to adults in the "andrology" profile leads to the fact that the andrologist does not have a regulated status. Due to the fact that such a specialty, namely, the andrologist, is absent in the nomenclature of the specialties of specialists with higher medical and pharmaceutical education (Order of the Ministry of Health of Russia, 2015), the corresponding assistance to the population is carried out primarily by a urologist. The absence of an andrologist reduces the quality of medical services for men with specific diseases that affect their reproductive function, and, accordingly, violates their right to receive high quality medical care. Indeed, an important feature of andrology is its relationship with other medical disciplines. It lies at the junction of urology, endocrinology and psychiatry. The problems of andrology are dealt with by doctors of a different profile, whose actions are limited by the scope of their specialty. In this regard, the opinion of the medical community about the professional place of the andrologist in the structure of modern medicine remains uncertain, which makes it impossible to develop this area of clinical medicine. Patients suffering from "male" diseases, are at the same time at a loss what doctor to contact. "The development of individual standards and algorithms for the diagnosis and treatment of andrological patients is considered necessary by $77.8 \%$ of urologists and andrologists, and $88.2 \%$ of doctors of other specialties" (Smolianinov, 2009). These indicators indicate that the definition of the social role of the andrologist as a specialist in male health is necessary in order to regulate, systematize the market for medical services, improve the quality of medical care for men, and improve the demographic situation in the country. In particular, according to recent $\mathrm{WHO}$ data, male infertility accounts for about half of cases (Churakov).

Due to the lack of a specialized doctor for "male" diseases, in practice, urologists provide 
medical assistance to them. Urology is a science that studies the diseases of the male and female genitourinary system. Andrology studies exclusively male physiology and the pathology of the reproductive system and genitals. A urologist-andrologist diagnoses and treats both women and men based on their physiological differences (Maksimov, Khromov, Iarovoi, Prokhorov 2011). To solve this problem, in our opinion, it is necessary to amend the name of the procedure for providing medical care to the adult population according to the profile "urology", designating the profile "andrology" by analogy with the procedure for providing medical care to the profile "pediatric urology-andrology".

President of the Professional Association of Andrologists P.A. Shcheplev, Director of the Research Institute of Urology, Professor O.I. Apolihin indicate that in Russia, andrology is recognized as a medical specialty only de facto, while de jure andrology, as such, does not exist. Currently, when conducting a comprehensive analysis of andrology and the provision of andrological assistance, the uncertainty of its legal status is ascertained, first of all (Apolikhin, Moskaleva, Komarova, 2019).

Professor O.I. Apolikhin in the framework of the All-Russian Congress on Andrology made a proposal: "In order to develop the andrological service, put it on a legally defined scientific path, the training of specialists in this branch of medicine should begin with the study of urology, and then continue with deepening knowledge in the problems of male health, supplementing them with related specialties, without the knowledge of which it is impossible to provide high quality andrological medical care" (Shaderkin, Danilov, 2007). Moreover, he suggests creating centres for male reproductive health, developing evidence-based standards for treating diseases of the male reproductive system, and a passport for reproductive health (Ministry of Health, 2019). It is impossible not to support this competent opinion.

In the same way, andrologists have been trained since 2003 in Germany, where urologists have been studying for 18 months un- der the program of continuing education in the "andrology" profile. German andrologists provide medical care in the field of reproductive technologies, in case of genetic disorders, ejaculation disorders, erectile dysfunction, explain questions to patients related to family planning (Kliesch, Weidner, 2011). Andrologists are competent to correctly assess the situation and refer patients for interdisciplinary support to specialists such as psychologists, psychotherapists, and psychiatrists (Schloeg1 et al., 2017)

It is important to note that in Russia there is a Professional Association of Andrologists, whose activities are aimed at bringing together specialists interested in uro-andrology, however, it should be admitted that most of the participants in this association are doctors of the following specialties: urologists, surgeons, sexologists, endocrinologists, rather than andrologists. The Association organizes various conferences, congresses to discuss problems of infertility, sexual dysfunction, pediatric andrology, urogenital infections, etc. (Official site of the Professional Association of Andrologists of Russia).

The problems we have examined over the past 30 years have worried not only Russian but also foreign experts in the field of andrology. So, in 1992, in order to increase the level of scientific knowledge, develop clinical recommendations, and treatment standards for the andrology profile, the European Academy of Andrology (EAA) was founded in Europe. To achieve the same goals, EAA training centers were actively opened in different countries, and already in 2015 there were 24 such centres in Europe, as well as one in the USA (Los Angeles) and one in Egypt (Cairo), where you can master the training program for doctors in andrology. In Italy and Spain, the training of doctors in this profile is carried out for two years, it is available not only to urologists, but also to endocrinologists and gynecologists. With the participation of andrologists in European countries, they treat prostate diseases, testicular cancer, inflammation and infections of the genitourinary system, and sexual dysfunctions of men. In addition, operational andrology is rapidly developing (Krausz, Brannigan, Sig- 
man, 2015). In our opinion, the exchange of experience between the EAA and the Professional Association of Andrologists of Russia, the cooperation of these organizations will help to improve the professional level of domestic andrology.

Recognizing the importance of the role of the andrologist as a specialist in male health is a necessary factor in regulating and systematizing medical care for men, improving its quality in the field of prevention, diagnosis, treatment (conservative and surgical) and rehabilitation of men, which will undoubtedly lead to an improvement in demographic situation in the country (Tsang, Wassersug, 2018).

Despite the fact that andrology is a relatively young, developing medical discipline, it is very important for ensuring reproductive male health. At universities, students study this discipline within the framework of the discipline "Urology" and partly when studying related andrology disciplines (neurology, psychiatry, therapy, surgery, endocrinology, dermatovenerology), but this training system does not allow the student to form a holistic view, understanding of the physiology and pathology of the male body (Whale, 2014). The curriculum does not study a number of important problems of male health, for example, infertility, sexual disorders. It is important to note that earlier andrology was studied in universities in the framework of a separate discipline, but this course was abolished. In this regard, we consider it necessary to include the study of andrology as an independent educational discipline in the Federal State Educational Standard.

\section{Conclusion}

Thus, the Russian legislation is mainly aimed at ensuring and protecting women's health, which leads to a violation of men's rights and gender discrimination of men in the field of the realization of reproductive rights and a contradiction to Part 3 of Art. 19 of the Constitution of the Russian Federation, fixing the equal rights of men and women and equal opportunities for their implementation.

The realization of the rights of men to state health care in terms of providing specialized medical assistance in the field of human reproduction faces a number of problems that are associated with the lack of a properly organized structure for the provision of andrological medical care, and therefore the level and quality of specialized medical care for men with diseases of the reproductive organs the system remains inadequate. In this regard, it is necessary to consider andrology" as a sub-specialty within the main medical specialty "urology", develop programmers for the training of andrologists, and also include this specialty in the field of male reproduction, in the nomenclature of the positions of medical workers and pharmaceutical workers. In order to improve the professional level of domestic andrology, it is necessary to take into account the experience of foreign countries in this field, in particular, expand cooperation between the Professional Association of Andrologists of Russia and the European Academy of Andrology. These measures will provide the necessary level of medical care for men with diseases of the reproductive system more effectively.

\section{References}

Apolikhin, O.I., Moskaleva, N.G., Komarova, V.A. (2015). Sovremennaia demograficheskaia situatsiiai problem uluchsheniia reproduktivnogo zdorov'ia naseleniia Rossii [The current demographic situation and the problems of improving the reproductive health of the Russian population]. In Ekspertnaia $i$ klinicheskaia urologica [Expert and clinical urology], 4, 4-14.

Apolikhin O.I., Moskaleva N.G., Komarova V.A. (2019). Sovremennaia demograficheskaia situatiia i problemy uluchsheniia reproduktivnogo zdorov'ia naseleniia Rossii [The current demographic situation and the problems of improving the reproductive health of the population of Russia]. Available at: https:// www.uroweb.ru/article/sovremennaya-demograficheskaya-situatsiya-i-problemi-uluchsheniya-reproduktivnogo-zdorovya-naseleniya-rossii (accessed 20 December 2019).

Bagrintseva, M. (2020). Vsemirnyi Den' bor'by protiv raka [World Cancer Day]. Available at: https:// www.pnp.ru/social/vsemirnyy-den-borby-protiv-raka.html (accessed 04 February 2020). 
Geneticheskie prichiny besplodia (muzhskogo i zhenskogo) [Genetic causes of infertility (male and female)]. Available at: https://www.yamed.ru/services/genetika/geneticheskie-prichiny-besplodiya/ (accessed 20 December 2019).

Churakov, A.A. O nekotorykh aspektakh muzhskogo besplodiia. MTs Vrachebnaia praktika [On some aspects of male infertility. MC Practice]. Available at: http://www.vpsaratov.ru/articles/259/ (accessed 20 December 2019).

Churakov, A.A. Dostuchatsia do patsienta ili nekotorye mify i realnost o besplodii. MTs Vrachebnaia praktika [Reach out to the patient or some myths and reality about infertility. MC medical practice]. Available at: http://www.vpsaratov.ru/articles/115/ (accessed 20 December 2019).

Korobkov, D.M. (2016). Trubno-peritonial' noe besplodie u zhenshchin reproduktivnogo vozrasta i ego kliniko-faktornyi analiz. Biulleten' nauki i praktiki [Tube-peritoneal infertility in women of reproductive age and its clinical and factor analysis]. In Elektronnyi zhurnal [Bulletin of science and practice], 12 (13), 186-189.

Korobkov, D.M. (2016). Primenenie metodov ul' trazvukovoi diagnostiki v kachestve prognosticheskogo kriteriia riska razvitiia ne vynashivaniia i platsentarnykh narushenii. [Application of ultrasound diagnostic methods as a prognostic criterion for the risk of developing habitual miscarriage and placental disorders]. In Biulleten' nauki i praktiki [Bulletin of science and practice], 12 (13). 179-181.

Korobkov, D.M., Vechkanova, N.A. (2016). Immunobiokhimicheskaia otsenka kliuchevykh pokazatelei oksidativnogo stressa u patsientok pri naruzhnom genital'nom endometrioze v sochetanii s gipotireoidnoi patologiei [Immunobiochemical evaluation of key indicators of oxidative stress in patients with external genital endometriosis combined with hypothyroid pathology]. In International Research Journal, 12-5 (54), 91-92.

Kliesch S, Weidner W. (2011). Removal of and urology from the specialty training programme in urology: a step forward or backward: initial assessment. In Urologe A. 2011 Aug; 50 (8): 952-957. DOI: 10.1007/ s00120-011-2547-1.

Krausz, C, Brannigan, R.E, Sigman, M. (2015). Subspecialty training in andrology. In Fertility and sterility. 2015 July; 104 (1): 12-15. DOI: http://dx.doi.org/10.1016/j.fertnstert.2015.04.038.

Maksimov, V.A., Khromov, R.A, Iarovoi, S.K., Prokhorov, A.V. (2011) Sovremennoe sostoianie ekstrennoi andrologicheskoi pomoshhi v g. Moskve [The current state of urgent andrological care in Moscow]. In Meditsinskie tekhnologii. Otsenka i vybor [Medical technologies. Evaluation and selection], 3, 44-48.

Minzdrav razrabotaet pasport reproduktivnogo zdorovia dlya muzhchin $v$ Rossii [Ministry of Health will develop a reproductive health passport for men in Russia]. Available at: https://katun24.ru/news/528981 (accessed 20 December 2019).

Ob utverzhdenii Poriadka okazaniia meditsinskoi pomoshchi po profiliu "detskaia urologiia-andrologiia": Prikaz Minzdrava Rossii (po sostoianiiu na 29.10.2012) (podgotovlen Minzdravom Rossii) (podpisan 31.10.2012 № 561n) [On the approval of the Order of medical care for the profile of "children’s urology-andrology": the order of the Ministry of Health of Russia (as of 29.10.2012) (prepared by the Ministry of Health of Russia) (signed on October 31, 2012 No. 561n)]. Available at: https://www.rosminzdrav. ru/documents/6631-prikaz-minzdrava-rossii-ot-31-oktyabrya-2012-g-561n (accessed 20 December 2019).

Ob utverzhdenii Poriadka okazaniia meditsinskoi pomoshchi vzroslomu naseleniiu po profiliu "urologiya”: Prikaz Minzdrava Rossii ot 12.11.2012 № 907n (zaregistrirovano v Miniuste Rossii 29.12.2012 № 26478) [On the approval of the Order of medical care for adults in the profile of "urology": Order of the Ministry of Health of Russia from 12.11.2012 № 907n (registered in the Ministry of Justice of Russia on 29.12.2012 No. 26478)]. In Rossiiskaia gazeta. Spetsvypusk [Russian newspaper. Speciallssue], 78/1, 11.04.2013.

Ob utverzhdenii Poriadka okazaniia meditsinskoi pomoshchi po profiliu "akusherstvo i ginekologiia" (za iskliucheniem ispol'zovaniia vspomogatel'nykh reproduktivnykh tekhnologii): Prikaz Minzdrava Rossii ot 01.11.2012 № 572n (red. ot 12.01.2016) (Zaregistrirovano v Minyuste Rossii 02.04.2013 № 27960) [On approval of the Order of medical care in the profile of "obstetrics and gynecology" (except for the use of assisted reproductive technologies): Order of the Ministry of Health of Russia from 01.11.2012 № 572n (as 
amended on January 12, 2013) (registered in the Ministry of Justice of Russia on 02.04.2013 No. 27960)]. In Rossiiskaia gazeta. Spetsvypusk [Russian newspaper. Special Issue], 90/1. 04/25/2013.

O nomenklature spetsial'nostei spetsialistov, imeiushchikh vysshee meditsinskoe i farmatsevticheskoe obrazovanie: Prikaz Ministerstva zdravookhraneniya RF ot 7 oktiabria 2015 g. № 700n (red. ot 11.10.2016) (zaregistrirovano v Miniuste Rossii 12.11.2015 № 39696) [On the nomenclature of specialties of specialists with higher medical and pharmaceutical education: Order of the Ministry of Health of the Russian Federation of October 7, 2015, No. 700n (as amended on October 11, 2016) (registered with the Ministry of Justice of Russia on November 12, 2015 No. 39696)]. In Biulleten' normativnykh aktov federal"nykh organov vlasti [Bulletinofnormativeactsoffederalexecutivebodie], 1, 12.21.2015.

Official site of the Professional Association of Andrologists of Russia. Available at: http://www.andronet.ru/paar/ (accessed 20 December 2019).

Rybalchenko, S.I. (2015). Sotsia'no-demograficheskie aspekty reproduktivnogo zdorov'ia natsii. [Socio-demographic aspects of reproductive health of the nation]. In Doklad na Mezhdunarodnom forume "Novye gorizonty reproduktivnogo zdoroivia" [Report at the International Forum "New horizons for reproductive health"]. Moscow.

Smolianinov, A. (2009). Professional'nyi status i sotsial'naya rol'vracha-androloga v sovremennoi rossiyskoi meditsine: avtoreferat dis. kand. med. nauk [Professional status and social role of andrologist in modern Russian medicine: Abstract of Thesis of Candidate of Nedical Sciences]. Volgograd, $27 \mathrm{p}$.

Shaderkin, I.A., Danilov, I.A. (2007). Otchet o provedenii Vserossiiskogo kongressa po andrologii. 27-29 aprelia 2007 goda, g. Sochi. UD Prezidenta RF. [Report on the All-Russian Congress on Andrology. April 27-29, 2007, Sochi. under the auspices of the President of the Russian Federation]. In Andrologiia $i$ genital'naia khirurgiia [Andrology and genital surgery], 2, 71-74.

Schloegl, I., Köhn, F.M., Dinkel A., Schulwitz H., Gschwend J.E., Bosinski H.A., Herkommer K.E. (2017). Education in sexual medicine - a nationwide study among German urologists/andrologists and urology residents. In Andrologia. 2017 Mar; 49 (2). DOI: 10.1111/and.12611.

Torosyan, R.A. (2017). Konstitutsionnoe regulirovanie zapreta diskriminatsii muzhchin v Rossii: avtoreferat dis. kand. yurid. nauk [Constitutional regulation of the prohibition of discrimination of men in Russia: Abstract of Thesis of Candidate of Juridical Sciences], Penza, 31p

Tsang, V.W.L, Wassersug, R.J. (2018). Men's health research versus andrology - defining the division and closing the divide. In Journal of Men's Health, 14 (3), 20-32. DOI: https://doi.org/10.22374/18756859.14.3.2.

Whale, E.M. (2014). Usovershenstvovanie prepodavaniia andrologii na tsikle urologii - velenie vremeni [Improvement of teaching andrology in the cycle ofurology - sign of time]. In Zdorov'e muzhchiny [The Health of Man], 48, 1, 157-158. 